\title{
Skills Shortage in South Africa: Interrogating the Repertoire of Discussions
}

\author{
Antonio Domingos Mateus \\ Faculty of Business, Cape Peninsula University of Technology, South Africa \\ Email: manuchot25@gmail.com \\ Charles Allen-lle \\ Faculty of Business, Cape Peninsula University of Technology, South Africa \\ Email: allenilec@cput.ac.za \\ Chux Gervase Iwu \\ Faculty of Business, Cape Peninsula University of Technology, South Africa \\ Email: iwuc@cput.ac.za
}

\section{Doi:10.5901/mjss.2014.v5n6p63}

\section{Abstract}

The object of this paper was to examine skills shortage in South Africa specifically to unearth the myriad arguments around the subject but more importantly to unveil what has consistently lacked in the narratives of previous authors on the subject. In this regard, this paper has provided interesting insights into the attempts by countries such as New Zealand and Australia in stemming the tide of the scourge. The authors chose literature review as the main source of data collection. The paper also dishes what the authors consider as possible remedies to the scourge, while it advises that the problem of skills shortage is not the exclusive preserve of government. Further, the authors acknowledge that although the National Skills Development Strategy (NSDS) and its learnership programmes have experienced a huge amount of criticism, skills development is and will remain a dynamic and evolving process for addressing skills shortage as a long term strategy. There is no doubt that this paper has value in that it draws attention to the various issues associated with skills shortage especially in South Africa. Although the problem of skills shortage has been previously identified, it should be noted that it presents a significant problem in any society, and therefore demands regular attention.

Keymords: Scarce skills, South Africa, HIVIAIDS, Pull Factors, Push Factors, Skills Shortage

\section{Introduction}

International trends suggest that skills shortage is a global phenomenon. Countries, employers and organisations worldwide continuously express their unhappiness regarding a shortage of skilled professionals in various sectors of their economic activities.

In Australia for instance, skills shortage is faced by three broad occupational areas namely professional occupations; skilled trades; and service occupation, which represent a large number of professions or sectors. Like Australia, several new members of the European Union (EU) such as Hungary, Poland, Slovak Republic and the Czech Republic are also reported to be in the same situation including low employment rates, especially among unskilled workers. Evidence of skills shortage in Central Europe is linked to faster labour relocation and convergence to EU affluent countries.

Pat Galagan reported in a 2010 study that 79 per cent of the 1,179 organisations sampled in the United States of America confirmed that they were experiencing severe skills shortage in their industries. The study further reported that reasons for this were basically two-fold namely the difference in the needs of industries and graduate attributes. The other was that industry jobs require more knowledge work, more teamwork, and more use of technology than in the past. These reasons tend to suggest that there is a serious mismatch between current workforce and organisations' strategies leading one to believe that either the curriculum of schools and colleges are not focusing on the needs of industries or an aging baby-boomer population is contributing to labour shortage in the USA.

In Africa, while the above reasons may suffice, HIVIAIDS is considered as one of the main reasons for the shortage of skilled professionals in the region. According to Coombe (2000) and Nkomo (2010), HIVIAIDS poses 
immense socioeconomic development challenges in South Africa. In fact, Mail \& Guardian (2008) estimated that half of the deaths in South Africa and $71 \%$ of the deaths among those between the ages of 15 and 49 are caused by Aids, hence the devastation among the young and middle-aged populations who should be filling the skills gaps.

Expressions of concern about South Africa's skills shortage is not something new, but has become more apparent in recent years. The Centre for Development and Enterprise (CDE) (2007:19) argues that skills shortage in South Africa is entirely because of increasing demand, which is driven by more rapid growth coincided with continuing supply pressures. These are caused by pull factors of the global skills market and the country's inability to develop, utilize, and retain enough human capital from its own resources. In this regard, Bohlmann (2010:1) and Crush and McDonald (2002:1) believe that South Africa is no different from the rest of the world where the migration of skilled professionals has generated considerable public attention during and since the fall of Apartheid.

This paper draws inspiration from several studies. Firstly is Bradley et al's (2012) work on Capital is not enough: Innovation in developing economies. Bradley and his team warned that while financial capital was equally central to economic development, one should note that 'capital alone is not a 'silver bullet' for the problem of poverty in developing economies'. They also add that it was important to focus on the individual in poverty reduction efforts. This somewhat suggests that the individual brings skills which are pertinent to socioeconomic development. The other significant inspiration for this paper is that given the increased interest in Africa; specifically South Africa, this paper undertakes a review of skills shortage in South Africa with a view to reflect on the causes and impact of skills shortage in South Africa, as well as examine measures taken by other governments in addressing skills shortages in their respective countries. The two countries that will be discussed here are New Zealand and Australia. The uniqueness of these two countries is in their long standing socio-political relationship with South Africa (Limb, 2008). It is hoped that through this, the government of South Africa and other stakeholders will gain some interesting insight into the scourge (skills shortage) and possibly fathom how it can be managed. It is equally important to note that this paper does not in any way suggest that the government of South Africa does not or has not intervened in dealing with this problem. The authors acknowledge that there are programs at various levels of government including private organisations which look at the issue of skills development and scarcity. Statutes such as Skills Development Act (SDA), Skills Development Levies Act (SDLA), National Skills Fund (NSF), and National Skills Development Strategy (NSDS) and so on, are also acknowledged. However it is the intention of this paper to persuade all stakeholders to rethink these programs and legislations in order to build a more sustained discourse in this regard.

\section{Reasons for Skills Shortage in South Africa}

Richardson (2007:8) describes the shortage of skills as a source of aggravation to firms and, when severe, it is likely to hamper the quality and quantity of industrial development outputs. Richardson also argues that skills shortage in South Africa comes from many origins, namely a lack of investment in skills development; education; and rapid structural change, which is combined with low levels of overall unemployment; a cyclical surge in employment in parts of the economy; and because of a weakness in the training system. For instance, during the launch of the Joint Initiative on Priority Skills Acquisition (JipSA), it was acknowledged that one of the deepest scars of Apartheid was certainly the denial of acquisition of quality education and skills for Black people (JipSA, 2007:2). As a result, skills shortage was long identified as one of the critical constraints to economic growth and employment creation by the South African government. Thus, in an effort to address the problem, the government created the Sector Education and Training Authorities (SETA) in 2000 with an aim to assist in the fight against poverty, lack of employment opportunities and fulfilling equity employment targets (Akoojee \& McGrath, 2007; Mail \& Guardian, 2007).

Akoojee and McGrath (2007:424) provide additional reasons for skills shortage in South Africa, namely the Apartheid system, where skills were profoundly racialised and gendered, which left Black, particularly female Black South Africans in complete denial of access to skills development. Much later in 2009, Breier and Erasmus concurred by placing the blame on skills shortage on an education system that still suffers from decades of neglect and dysfunction from Apartheid when Black people were educationally underprivileged. They also point to the insufficient education system that does not generate the necessary skills needed for the country's economy. In essence, Breier and Erasmus are of the opinion that both the quantity and quality of education provided to the majority of South Africans in the past lacked substance.

The immigration of South African skilled professionals to other parts of the world such as the USA, the UK, Australia, New Zealand, and Canada is also mentioned as a contributing factor. Crush and McDonald (2002:1) confirm that many South African skilled professionals migrated to other parts of the world during the advent of the new political dispensation, as they feared the effects of Affirmative Action policies, crime and violence, and other policies that have 
also worked against the country's skills shortage.

Various studies (Alam \& Hoque, 2010:535; Crush \& McDonald, 2002:1; and Fourier, 2006:44-45) relate skills shortage in South Africa to the rise of migration of skilled professionals and other forces. Some of these forces include internal and external factors. However, Kline (2003:108) classifies these forces as push and pulls factors. According to Garbayo and Maben (2009:1), push factors are generally present in giving countries, while pull factors pertain to receiving countries. Therefore, Alam and Hoque (2010:535) and Fourier (2006:44-45) describe the internal/push factors and external/pull factors in the table (Table 1) below. Rasool et al. (2012: 12) add racial differentiation and job security to the list of internal and external factors respectively.

Table 1: Push and Pull Factors of migration in South Africa

\begin{tabular}{|l|l|}
\hline \multicolumn{1}{|c|}{ Internal/push factors } & \multicolumn{1}{c|}{ External/pull factors } \\
\hline Crime & Wage differentials \\
\hline Fear of the Aids epidemic & Differences in quality of life \\
\hline High unemployment rate & Educational opportunities for children \\
\hline Unequal levels of education & Intellectual freedom \\
\hline Low eroding wages and salaries & Political stability \\
\hline
\end{tabular}

Alam and Hoque (2010:535) and Fourier (2006:44-45) argued that the above factors have somehow contributed to a reduction of skills in South Africa owing to the fact that many skilled professionals are lured by better working conditions and career development opportunities, which are presented to them in developed nations. Furthermore, Crush and McDonald (2002:1); Du Preez (2002); and Szlontai and Stern (2006) argue that both push and pull factors also lead to depletion or loss of intellectual and technical personnel, with a negative outcome that impacts the economic and social growth of a country.

\section{Evidence of Skills Shortage in South Africa by Occupation}

The Solidarity Research Institute (SRI) (2008:2) argued that the 2007 report, which was released by Deloite \& Touché, indicated that $81 \%$ of South African companies struggle to find appropriate staff, with $76 \%$ having difficulty finding employment equity candidates, in particular. According to SRI, the evidence lies in the particular shortage of chartered accountants, IT specialists, sales and marketing personnel, and scientists. Also, according to SRI (2008), both the South Africa Institute of Architects and the Institute of Draughting are also experiencing a shortage of skilled professionals. In 2011, figures released by Adcorp showed over eighty two thousand unoccupied positions in high-skilled occupations in South Africa (Polity.org). As SRI (2008) indicated, the Human Sciences Research Council found that there is a shortage of between 350000 and 500000 qualified people to fill managerial and technical positions (SRI, 2008:5). Many of these may have emigrated. The CDE (2010) found that over one hundred and twenty professionals left South Africa. Countries such as the United Kingdom, Australia, New Zealand and USA were the beneficiaries of professionals in medicine, engineering, accounting and law. Other fields include artisans and technicians; and occupations in the agricultural industry.

\subsection{Sectoral trends on skills shortages}

\subsubsection{Artisans}

In order to understand the nature of artisans in South Africa, it is important to consider what artisans' skills are, and the sectors in which they engage. According to Breier and Erasmus (2009:251), the term artisan is derived from the Latin word artire, which means to instruct through arts. The term referred to skilled workers who could make things by hand, and this practice continued until the end of the Middle Ages with the introduction of apprenticeships. Despite the fact that it is crucial to have sufficient artisans in South Africa to enable infrastructure development, economic growth and wealth creation, many studies continue to show evidence that the country faces a severe shortage of artisans, which hinders government's ability to sustain the kind of development and economic growth that is needed for the eradication of poverty (Van Rooyen et al. 2010:1; Breier \& Erasmus, 2009:1; and Engineering News, 2005).

The Service Publication ( 2010) argued that South Africa produced less than $45 \%$ of the number of artisans that were required in the economy, and less than half the number that it produced a quarter of a century ago. Perhaps this is 
one of the reasons why municipalities battle to render proper services. Artisans are critical for the operation and maintenance of municipal infrastructure and equipment. Their shortage however is not only evident in government, where their work is visible and required for maintaining and keeping the lights on, ensuring water accessibility to all, and maintaining roads and bridges. The private sector is also feeling the same scarcity; a lack of artisans is evident in manufacturing, mining and other heavy duty industries.

The Solidarity Research Institute (2008:3) and Service Publication (2010) conclude rather disappointingly that South Africa only had $10 \%$ of the artisans than it had 20 years ago, and estimations were that the country had a $40 \%$ shortage of artisans. This has forced entities such as construction company giant, Grinaker-LTA to import artisans from Malaysia, Ireland and India. Petrochemical company, Sasol, imported 1300 artisans from Thailand to work at the company's Secunda Synthetic Fuel Plant (Solidarity Research Institute, 2008:3).

The question arises therefore; what are the main reasons for a shortage of artisans in South Africa. According to John Botha, general manager of the Production Management Institute, a lack of suitably qualified candidates with qualifications in Science and Mathematics should be blamed (Service Publication, 2010). Van Rooyen et al. (2010:2) disagree. They would rather blame the shortage of artisans on organisations' failure to apply effective retention strategies. According to Barry and Jordaan (2009:174), reasons for the shortage could also be linked to globalisation because international organisations also recruit artisans in South Africa. This somewhat indicates that past learnership programmes are recognised as world class, not to mention the high salaries that are offered by these international organisations, in conjunction with the social issues of high crime rates, and violence in South Africa.

In opposition to the claims above, Breier and Erasmus (2009:220) blame the massive shortage of artisans largely on a decline in apprenticeship systems and the failure of substitute interventions, which include training via learnerships and further education and training colleges to eliminate the backlog. Breier and Erasmus add that a majority of young people who have received some form of artisan training do not find jobs after graduation because they have not had sufficient or appropriate work experience, or their course was not aligned to industry requirements.

The Service Publication (2010) makes a rather disturbing disclosure that a major setback came as a result of two major companies, namely Eskom and Telkom who were responsible for training a large segment of artisans through apprenticeships, but ended the programme due to the commercialisation of their operations.

\subsubsection{Nurses}

The shortage of nurses is a chronic problem in South Africa. Many hospitals in the rural areas and small towns do not have adequate health personnel. Yet there are many South African nurses who work overseas. Garbayo and Maben (2009:2) and Kuehn (2007:1853) note that a global shortage of healthcare workers has become a major concern for both developing and developed countries, especially since the government of South Africa wishes to eliminate mortality among children during birth, rising vaccine exposure, and epidemics such as HIVIAIDS.

However, regardless of the number of available health professionals, the World Health Organisation (WHO) (2006) states that various factors have contributed to the existing global shortage of nurses internationally and that these factors have left developed nations with too few domestic health workers to meet local demands. These factors include the growing aging population in developed countries, predominantly in the northern hemisphere; the increasing demand for high-tech health care workers, poor planning and under-investment in health workers' education.

According to Garbayo and Maben (2009:2), in Africa, the health systems have been badly damaged owing to migration of its health professionals to more developed countries, leaving an immense vacuum in the sector and the continent as a whole. As a consequence of these migration patterns, Africa has 2.3 health personnel per 1000 inhabitants, compared to the Americas, where there are 24.8 healthcare workers per 1000 inhabitants (Naicker et al. 2009). Ethiopia is an example of the many African nations that face a devastating shortage of health professionals. According to Dorman et al. (2009:622), during 2006 there were only 0.03 doctors per 1000 people with an even lower ratio in surgery.

In South Africa, the system comprises a dual health system, namely the private and public sector. The public sector comprises government health institutions with a mandate to predominantly serve the impoverished population of the country. The private sector comprises individual businesses that serve for profit, and provide healthcare services to the insured with economic standards.

Pillay (2009:1) states that in spite of the fact that the public sector is responsible for the well-being of $82 \%$ of the population, it accounts for only $40 \%$ of total health expenditure, whilst the private segment consumes $60 \%$ of the health expenditure, yet responsible for less than $20 \%$ of the population. Pillay also notes that the public sector is often characterised as inefficient and ineffective in terms of meeting its mandate of accessibility, affordability and providing 
appropriate health care, as it is under-resourced and overused, while the private sector is more apparent for its worldclass facilities and care provision.

Various reasons seemed to have contributed to the shortage of nurses in South Africa, and these include HIVIAids that affects many health workers, as well as poor working conditions, crime, a fragile economy, uncertainty of children's' future, discriminatory laws, lack of personal and professional development, and higher pay rates abroad. Meanwhile, the WHO (2006) considers factors such as economic policies, limited investment in public sector healthcare and reduced funds for health personnel education as core contributors to the shortage of nurses in various less-developed countries. WHO warned that without proper policies, the situation would worsen. Below is an illustration of the South African Nurse Council's distribution for 2008.

Table 2: SANC Geographical Distribution 2008. Geographical distribution of the population of South Africa versus nursing human resources

\begin{tabular}{|c|c|c|c|c|c|c|c|c|}
\hline & \multirow{2}{*}{$\begin{array}{c}\text { Population } \\
2008\end{array}$} & \multicolumn{4}{|c|}{ Nursing Human Resource as at $2008 / 12 / 31$} & \multicolumn{3}{|c|}{ In Training as at 2008/12/31 } \\
\hline Province & & Registered & Enrolled & Auxiliaries & Total & Students & Pupils & Pupil N/A \\
\hline \multicolumn{9}{|l|}{ Limpopo } \\
\hline - Females & 2768100 & 7537 & 2836 & 6823 & 17196 & 1277 & 267 & 332 \\
\hline - Males & 2506700 & 835 & 363 & 853 & 2051 & 476 & 37 & 92 \\
\hline - Total & 5274800 & 8372 & 3199 & 7676 & 19247 & 1753 & 304 & 424 \\
\hline \multicolumn{9}{|l|}{ North West } \\
\hline - Females & 1756200 & 6342 & 1996 & 4048 & 12386 & 1094 & 21 & 130 \\
\hline - Males & 1668800 & 705 & 191 & 538 & 1434 & 335 & 7 & 24 \\
\hline - Total & 3425000 & 7047 & 2187 & 4586 & 13820 & 1429 & 28 & 154 \\
\hline \multicolumn{9}{|l|}{ Mpumalanga } \\
\hline - Females & 1859100 & 4903 & 1630 & 3063 & 9596 & 286 & 195 & 85 \\
\hline - Males & 1730900 & 400 & 144 & 292 & 836 & 140 & 26 & 31 \\
\hline - Total & 3590000 & 5303 & 1774 & 3355 & 10432 & 426 & 221 & 116 \\
\hline \multicolumn{9}{|l|}{ Gauteng } \\
\hline - Females & 5248600 & 26874 & 10379 & 15042 & 52295 & 3299 & 3894 & 2330 \\
\hline - Males & 5198500 & 1312 & 682 & 1068 & 3062 & 701 & 361 & 134 \\
\hline - Total & 10447100 & 28186 & 11061 & 16110 & 55357 & 4000 & 4255 & 2464 \\
\hline \multicolumn{9}{|l|}{ Free State } \\
\hline - Females & 1506800 & 6506 & 1278 & 2674 & 10458 & 751 & 186 & 133 \\
\hline - Males & 1370900 & 783 & 228 & 339 & 1350 & 245 & 47 & 40 \\
\hline - Total & 2877700 & 7289 & 1506 & 3013 & 11808 & 996 & 233 & 173 \\
\hline \multicolumn{9}{|c|}{ KwaZulu Natal } \\
\hline - Females & 5321100 & 21188 & 14307 & 10305 & 45800 & 2187 & 4242 & 970 \\
\hline - Males & 4784400 & 1280 & 1517 & 1075 & 3872 & 614 & 469 & 95 \\
\hline - Total & 10105500 & 22468 & 15824 & 11380 & 49672 & 2801 & 4711 & 1065 \\
\hline \multicolumn{9}{|c|}{ Northern Cape } \\
\hline - Females & 580500 & 1915 & 405 & 1195 & 3515 & 232 & -- & 92 \\
\hline - Males & 545400 & 156 & 30 & 119 & 305 & 58 & -- & 51 \\
\hline - Total & 1125900 & 2071 & 435 & 1314 & 3820 & 290 & -- & 143 \\
\hline \multicolumn{9}{|l|}{ Western Cape } \\
\hline - Females & 2760400 & 13421 & 4710 & 7527 & 25658 & 1437 & 717 & 365 \\
\hline - Males & 2501600 & 594 & 244 & 512 & 1350 & 321 & 66 & 27 \\
\hline - Total & 5262000 & 14015 & 4954 & 8039 & 27008 & 1758 & 783 & 392 \\
\hline \multicolumn{9}{|l|}{ Eastern Cape } \\
\hline - Females & 3441500 & 12400 & 2575 & 4998 & 19973 & 2296 & 498 & 104 \\
\hline - Males & 3137800 & 827 & 171 & 671 & 1669 & 708 & 146 & 23 \\
\hline - Total & 6579300 & 13227 & 2746 & 5669 & 21642 & 3004 & 644 & 127 \\
\hline \multicolumn{9}{|l|}{ TOTAL } \\
\hline - Females & 25242300 & 101086 & 40116 & 55675 & 196877 & 12859 & 10020 & 4541 \\
\hline - Males & 23445000 & 6892 & 3570 & 5467 & 15929 & 3598 & 1159 & 517 \\
\hline - Total & 48687300 & 107978 & 43686 & 61142 & 212806 & 16457 & 11179 & 5058 \\
\hline
\end{tabular}


Source: SANC Geographical Distribution 2008. South African Nursing Council - http://www.sanc.co.za/stats/stat2008 /Distribution\%202008xls.htm

The above table indicates that South Africa has 437 nurses for every 100000 people. This includes nurses in the "enrolled" and "auxiliary" categories as well. When only registered nurses (those who have completed a four year course) are considered, the ratio drops to 222 registered nurses for every 100000 people. This translates to a ratio of 451 people for every registered nurse. This is appalling.

\subsubsection{Doctors}

Doctors are in short supply globally. The worst hot are developing countries whose medical schools are regarded highly. Doctors in these countries are actively recruited by developed countries. In fact, Bezuidenhout, Joubert, Hiemstra and Struwing (2009:2012) note that 23\% of America's more than 770,000 doctors that were licensed in 2002 were trained outside the USA, and from this figure, 5,334 hailed from sub-Saharan Africa. Nearly $86 \%$ of 5334 of these doctors originated from Nigeria, Ghana and South Africa. Bezuidenhout et al. (2009:12) further state that $79.4 \%(4,234 / 5,334)$ of them were products of 10 out of the 87 medical schools in Africa. Five of the top-ten medical schools are in Nigeria, three in South Africa and one each in Ghana and Ethiopia. But with regard to the number of qualified doctors from these medical schools, the University of the Witwatersrand is top of the list (1 053 graduates), with the University of Cape Town second (655) and the University of Pretoria tenth (132).

Naicker et al. (2009:60) indicate that since 1996, 37\% of South African doctors had immigrated to places such as Australia, Canada, Finland, France, Germany, Portugal, the United Kingdom and the United States. Bezuidenhout et al. $(2009: 211)$ state that the number of South African doctors who work in Canada increased by more than $60 \%$ between 1996 and 2006, and they have been particularly poached because of the high standard of medical training that they received in South Africa.

Lewinsohn and Arnold (2010:288) affirm that healthcare in nations such as the United Kingdom, the United States, Canada and Australia, is heavily dependent on doctors from developing countries. Consequently, developing nations bear the cost of educating their citizens, but do not reap the fruits of their education, as many of these professionals are later attracted to go work in developed countries that offer better working conditions, better salaries and more opportunities to advance their careers. In South Africa, health systems suffer as a result of this. Evidence is in more than five thousand public health service vacancies that were announced for medical practitioners in 2006 alone (Breier \& Erasmus, 2009), while Breier (2007) noted that between 2004 and 2007, a large number of job vacancies that were advertised in the Sunday Times Career Supplement were not filled. Half of these vacancies were meant for health professionals.

Breier (2008: 31) states that from April 2004 to March 2007 the analysis showed that:

- There was a total of 112828 vacant positions advertised during this period;

- The leading share of job vacancy adverts were placed in search of professionals (50, 37 per cent) and managers (30, 52 percent);

- A total of 17479 vacancies were for health professionals, which accounted for 30,76 per cent of all professional vacancies over the three years under review; and

- Across the three year period, the largest share of job vacancy adverts in the health professionals category was placed in search of midwifery and nursing professionals (43,59 per cent), followed by vacancies for medical practitioners (35,87 per cent) and for health diagnostic and promotion professionals (16,04 per cent). Health therapy professionals accounted for 4, 50 per cent of the advertised vacancies.

Breier and Erasmus (2009:113) argue that the reason for the shortage of doctors in South Africa could be linked to both internal and external factors. This statement is welcomed by Lewinsohn and Arnold (2010:289), as well as Bezuidenhout et al. (2009:213) who also attribute the shortage of these health professionals to push and pull factors, in addition to other factors.

\subsubsection{Teachers}

Teacher shortage in South Africa is a controversial subject. And if we should consider whether there is in fact a shortage of teachers, Mda (2009) thinks it is critical that one examines perceptions against reality, and interrogate the interpretation of 'scarcity' and 'shortage'. According to Mda, using learner-educator-ratio (LER) of 40 to1 and 35 to 1, the 
picture one gets is that there is no scarcity of teachers. Instead, she says the uneven distribution of educators across provinces presented some concerns. She went on to say that while there were graduates in the field of education who were actively job hunting, the geographical areas in which they were seeking employment, were already oversubscribed.

Mda however does not dismiss the role of emigration in this case. According to her, while South Africa lacked skilled teachers, the few skilled ones had opted to go overseas in search of greener pastures and in some cases, some form of security. In fact, Mda states rather sternly that emigration of teachers to other countries is not a factor in the schools with predominantly African learners and educators.

In spite of the above, Breier and Erasmus (2009:200) state that the Department of Education (DoE) and the Department of Labour (DoL) consistently argue that there is no shortage of teachers, but nonetheless agree that there are skills issues that should be addressed. The latter may be in agreement with the statement made by Silva (2008) who stated that there is a serious shortage of skills in Mathematics and Science teaching, nationally, although the Western Cape is in a better position compared to other provinces.

\section{Impact of Skills Shortage in South Africa}

The impact of skills shortage is evidenced socially and economically. These are discussed below.

\subsection{Societal}

Leibbrandt et al. (2010: 4) state that skills shortage in South Africa builds social ills, particularly in townships and squatter camps, while it also contributes to high levels of unemployment and disparate families. This, according to Leibbrandt and the others, impacts negatively on levels of service both in the private and public sectors.

The above argument is supported by Wallis (2002:1) who suggests that skills shortage affects work performance widely owing to open vacancies that are available in firms; deteriorates the quality of customer service satisfaction; increases costs; and impedes or delays companies from developing new products.

According to CDE (2007: 11), the social effects of skills shortage in South Africa is felt in many different ways, including the anger of township and rural area residents who live in unsanitary conditions owing to a lack of engineers from the municipality, the erratic malfunctioning of public telephones, and frequently overflowing sewage systems caused by blockages and sudden cut offs of water and electricity, and the frustrations of employers who cannot find qualified candidates to fill vacant positions in their firms.

Various studies (CDE, 2007: 11; Ploch, 2011:13; Wallis, 2002:1 and Weatherburn, 2001:5) also relate the lack of skills and the high level of wealth disparity to be major contributors of poverty, crime and violence in South Africa. The above argument is supported by Babarinde (2009: 356) and Landman, Bhorat, van der Berg and van Aardt (2003:1) who state that most economists and political analysts agree that approximately $40 \%$ of South Africans, mainly Blacks who live in townships and in squatter camps across the country, live in precarious and impoverished conditions and have restricted access to basic services such as electricity, water, sanitation and other social services that would make them feel like human beings in a country that is somewhat well-off, while $15 \%$ of the poorest are involved in a desperate fight for survival owing to a lack of skills in the country.

\subsection{Economic}

While South Africa is seen as the economic giant of the continent of Africa, Bohlmann (2010:1) and Ploch (2011:1) state that South Africa is considered as one of the most unequal societies in the world in terms of income sharing in spite of its economic strength. According to Bohlmann and Ploch, a majority of the population, mostly Blacks, live in poverty, while the major cities are surrounded by informal settlements.

CDE (2010:9); Richardson (2007:8); and Rasool and Botha (2011:1) argue that economically, a lack of skills limits South Africa's economy from growing and contributes to high levels of unemployment. When the economy of a country is not growing, or creating jobs, it contributes to large volumes of unemployment and poverty, and prevents the country from being competitive in the global market. This argument is also held by Bohlmann (2010:1); Moser (1999:4) and Thornton (2008) who argue that the unavailability of a skilled workforce curbs business growth. Bohlmann (2010:1) adds that skills shortage also affect the country's social and economic development because investors are rather unwilling to invest given the fragility of the country's economy. 


\section{Response to Skills Shortage from Two Different Countries}

\subsection{New Zealand}

LaRocque (2007:1) states that the issues of skills shortage in New Zealand have been at the forefront of discussion in the business sector, national press and in government policy for some time now. Several sources such as the New Zealand Institute of Economic Research (NZIER), the Department of Labour (DoL), Business New Zealand and Grant Thornton, have highlighted that New Zealand have experienced, and continue to experience, severe skills shortage in almost every sector of their economic activity.

However, in response to emerging skills shortages in the country, the government launched the Skills Action Plan in 2002 to help manage the situation (NZDoL, 2005). One of the initiatives from this plan was the creation of the Job Vacancy Monitoring Programme within the Department of Labour. This programme hoped to improve the information on skills shortages throughout the country. It comprised a monthly monitor of job vacancies, which were advertised in newspapers and Internet job boards, an annual survey of employers who recently advertised, and in-depth reports on selected skilled occupations for which there were indications of shortages.

Specifically, Business New Zealand (2005) reported a few other interventions which included (1) an improved migration policy which allowed foreign nationals to take on employment in those scarce disciplines; (2) increased investment in training and apprenticeships; (3) a revision of employment laws; (4) improved literacy and numeracy campaigns; (5) more flexible provision of training; and (6) ensuring an adequate amount of teacher training and facilities.

The above strategies did not apply to all sectors though, rather to those occupations with severe skills shortages.

\subsection{Australia}

Like New Zealand, Australia also suffers from a severe shortage of skilled labour and as a result the Australian government at both state and national level put together different strategies to respond to the problem. One of those was the strengthening of the skills migration policy as a significant panacea to their skills shortage problem. This saw Australia becoming a net importer of skills from other countries. Also, a number of visa sub classes, which allow skilled migrants to live and work in Australia, were established. Since many of these sub classes are regionally or state sponsored, applicants are required to render services in selected regional areas for a minimum period of two years (Australian Government, 2006:35).

Another popular intervention was the Skilled Migration Program which provided the following:

1. An extension of the Working Holiday visa program for young people with reciprocal countries;

2. The introduction of additional changes to the Working Holiday visa to enable people who undertake at least three months' work in the construction sector in regional Australia to extend their twelve month holiday visa by another year;

3. A review of the temporary work visa system, which is also known as the subclass 457 visa program, to ensure efficiency in the supply of experienced professionals. This structure gives businesses a capability to skilled labour. This system allows businesses an ability to recruit skilled labour from overseas for temporary entry into Australia for periods of between three months and four years; and

4. The establishment of an External Reference Group made up of industry experts to examine how selected temporary skilled migration measures can help to ease labour shortages in the medium to long term.

The Australian Forum (2011) argues that another positive response, which was implemented by the Australian government to address the country's shortage and, which received industry blessing was the National Resources Sector Employment Taskforce, also known as (NRSET). This strategy recognised that Australia required more skilled workers if their economy should grow. Therefore, this strategy argues that while the country should improve training and boost apprenticeships, it was also essential to have programmes such as immigration programs, which are essential to deliver skilled workers when and where the country needed them.

Furthermore, the government of Australia introduced flexible training programs and apprenticeships and also compensated employers who took on trainees and apprentices through subsidies.

\section{Conclusion}

The shortage of critical skills has been part of the skills development debate in South Africa for some time. What is however surprising is that considering the huge numbers of graduates produced in different fields yearly, one wonders 
why the country is desperately in need of critical skills. One can hazard two guesses though namely (1) the graduates do not possess the critical skills that are sought after; and or (2) only few of the graduates possess the relevant skills needed.

The availability of requisite skills is central to South Africa's socioeconomic development. Sadly the country has faced severe skills shortages in almost every sector of its economic activity. While this impacts socioeconomic development, in comparison to other countries in the continent, South Africa fares much better with respect to poverty and unemployment. This perhaps explains why the country continues to attract immigrants of all sorts - the highly skilled and the not-so-highly skilled - from the African continent. Perhaps using the examples of Australia, New Zealand, and Germany, the government of South Africa can find creative ways of integrating these people into the mainstream of their economy. Maharaj (2004:2) argues that in spite of the vast disparity in poverty, unemployment and inequality in South Africa, the country is still home for many African immigrants who come from various parts of the continent. Many of these immigrants perceive South Africa as the land of hope, filled with enormous economic opportunities.

In fact, Murray (1995:374) argues that from its earlier days, South Africa was heavily dependent on migrant labour. Many southern African country immigrants were always welcomed and attracted to work in the mining and agriculture sector in South Africa and it never seemed to be a problem. Many of these migrants entered the country illegally, while many others entered the country legitimately to escape poverty, unemployment and destitution in their own countries, as well as civil war and political instability.

This paper has discussed the causes and impact of skills shortage in South Africa. The authors have also looked at measures taken by other governments in addressing skills shortages in their respective countries. There also has been an interesting insight into the different sectors in South Africa and the implication of skills shortage in those sectors.

This paper concludes by presenting certain recommendations that may serve not only the government of South Africa, but also other stakeholders. First is the issue of immigrant labour in South Africa. There are many strong arguments for and against the use of immigrant labour (especially African immigrant labour) in South Africa. One party talks about the exploitation of immigrants on the basis of how they are compensated, while another party accuses immigrants of job stealing. If well utilised, skilled immigrants will not take South African jobs away, but help to put the economy of the country in good shape; reduce levels of unemployment with their technical and entrepreneurial skills; and help government fight poverty by creating more jobs and reducing many social problems. Having said this, utilising the existing pool of foreign skilled immigrants in those sectors that struggle to find local expertise should serve short term benefits because it is expected that the government must step up in terms of training and developing its citizens.

Besides the use of African skilled foreigners who are already in the country, an improved migration policy from the Department of Home Affairs, in conjunction with the Department of Labour, would help bring a team of expertise that South Africa needs to help design training programmes that would help the country improve its literacy and numeracy programmes. This will no doubt improve the education system which is still trying to overcome neglect and dysfunction suffered under Apartheid. A more long term focus will be the enhancement of learning through education and lifelong learning enabling citizens' chances of being aptly employed. This can be done by equipping learners with basic employability skills such as literacy and numeracy and other important related life-skills for confidence building and selfesteem.

Government should create a programme which is aimed at improving the information on skills shortages throughout the country as such programme would help to monitor the monthly job vacancies that are advertised in newspapers, Internet, job boards, and all other forms of media where employers advertise for selected skilled occupations where there are shortages.

Combating the skills crisis should not be the exclusive preserve of government. South African government and its partners (employers, business, training establishments - colleges, universities - should work towards the development of learnership programs and curricula that adhere to the needs of business and government. In fact, these stakeholders should ensure that curriculum planning and coordination become a priority in learnership programme management. In particular, registration of learnership programmes and coordination of programmes should be assessed and audited according to rules laid down by both the Departments of Labour and Education in conjunction with business. It is important to ensure quality when teaching and learning imperatives are required. Offering qualifications for the sake of fulfilling quotas will not help either as it reflects in the tangible expression that learners will demonstrate in the actual workplace.

Government should invest more in education by building more training centres and facilities across the country, especially in previously and more disadvantaged areas because learners would emerge qualified with critical skills that will enable them to be self-reliant or even obtain a place in the labour market. This will help to eliminate high levels of unemployment, anti-social behaviours as well as eradicate levels of poverty. 
Although the National Skills Development Strategy (NSDS) and its consequential learnership programmes have experienced a huge amount of criticism, skills development is and will remain a dynamic and evolving process for addressing skills shortage as a long term strategy. Lastly, the progress of measures/recommendations made should be monitored regularly and evaluated to obtain best results. Further, a monitoring team or system of constant revision and monitoring of the plan's progress should be part of the entire plan to effectively monitor progress made regarding skills shortage.

Given the foregoing, perhaps the next set of questions (and possibly future research interests) should be:

(1) What policies or strategies would be suitable for South Africa's skills shortage taking into account the number of strategies and interventions in place?

(2) Granted that statutes such as SDA, SDLA, and NSF and NSDS and so on have been around for a while, one should ask: how effective are these statutes?

\section{References}

Alam, G. M., \& Hoque, K. E. (2010). Who gains from "Brain and Body Drain" Business-Developing/developed world or individuals: A comparative study between skilled and semi/unskilled emigrants. African Journal of Business Management, 4(4), 534-548.

Arnold, P. C., \& Lewinsohn, D. E. (2010). Motives for migration of South African doctors to Australia since 1948. Medical Journal of Australia, 192(5), 288-290.

Australian Forum. (2011). Australian government praised for efforts to increase skilled workforce. [Online] Available: http://www.australiaforum.com/information/jobs/australian-government-praised-for-efforts-to-increase-skilled-workforce.html (June 28 2011).

Babarinde, O. A. (2009). Bridging the economic divide in the Republic of South Africa: A corporate social responsibility perspective. Thunderbird International Business Review, 51(4), 355-368.

Barry, M.L \& Jordann, N. (2009). Investigating the reasons for lack of skilled artisans in South Africa: The perspective of artisans. South African Journal of Industrial Engineering, 20, 173-184.

Bezuidenhout, M.M., Joubert, G., Hiemstra, L.A. \& Struwing, M.C. (2009). Reasons for doctor migration from South Africa. South African Family Practice, 51, 211-215.

Bohlman, H. R. (2010). The macroeconomic impact of skilled emigration from South Africa: a CGE analysis. Melbourne: Centre of Policy Studies, Monash University.

Bradley, S. W., McMullen, J. S., Artz, K., \& Simiyu, E. M. (2012). Capital is not enough: Innovation in developing economies. Journal of Management Studies, 49(4), 684-717.

Breier, M. \& Erasmus, J. (2009). Skills shortages in South Africa: case study of key professions. Cape Town: HSRC, South Africa.

Breier, M. (2007). The shortage of medical doctors in South Africa. Case study forming part of the HSRC study: A multiple identification and verification of scarce and critical skills in the South African labour market. Cape Town: HSRC, South Africa

Business NZ. (2005). Skill shortages are now the single biggest issue facing business and are likely to remain one of the big issues for the foreseeable future. [Online] Available: http://www.businessnz.org.nz/file/1002/skills_perspectives.pdf (November 25 2013).

Centre for Development and Enterprise (CDE). (2008). Migration from Zimbabwe numbers, needs, and policy options. [Online] Available: http://www.cde.org.za/images/pdf/Migration\%20from\%20Zimbabwe.pdf (August 18 2013).

Coombe, C. (2000). Keeping the education system healthy: Managing the impact of HIVIAIDS on education in South Africa. Current Issues in Comparative Education, 3(1), 14-27.

Crush, J. \& McDonald, D. A. (2002). Destination to the unknown perspectives of brain drain in Southern Africa. Pretoria: South Africa.

Dorman, K., Satterthwaite, L., Howard, A., Woodrow, S., Derbew, M., Reznick, R., \& Dubrowski, A. (2009). Addressing the severe shortage of health care providers in Ethiopia: bench model teaching of technical skills. Medical education, 43(7), 621-627.

Engineering News. (2005). SA faces critical artisan shortage. [Online] Available at: http://www.engineeringnews.co.za/article/sa-facescritical-artisan-shortage-2005-12-16 (April 2011).

Fourier, A. (2006). Brain Drain and brain Circulation: A study of South Africans in the United Arab Emirates. M.Phil Thesis. Stellenbosch University.

Galagan, P. (2010). Bridguing the skills gap: Part 11. [Online] Available: http://www.astd.org/Publications/Magazines/The-PublicManager/Archives/2010/04/Bridging-the-Skills-Gap-Part-II (November 28 2013).

Garbayo, A.A. \& Maben, J. (2009). Internationally recruited nurses from India and the Philippines in the United Kingdom: the decision to emigrate. Human Resources for Health. Bio Med Central. [Online] Available at: http://www.human-resourceshealth.com/content/7/1/37) (March $7^{\text {th }}$ 2011).

http://www.info.1qwa33gov.za/otherdocs/2007/jipsarep.pdf (14 th April 2011).

Joint Initiative on Priority Skills Acquisition. (2007). [Online]. Available at:

Kline, D. S. (2003). Push and pull factors in international nurse migration. Journal of Nursing Scholarship, 35(2), $107-111$.

Kuehn, B. M. (2007). Global shortage of health workers, brain drain stress developing countries. JAMA: the journal of the American Medical Association, 298(16), 1853-1855.

Landman, J. P., Bhorat, H., Van der Berg, S., \& Van Aardt, C. (2003). Breaking the grip of poverty and inequality in South Africa: $2004-$ 2014. Trends, Issues, and Future Policy Options. Stellenbosch: EFSA (Institute for Theological \& Interdisciplinary Research). 
LaRocque, N. (2007). Skill Development and Skill Shortages in New Zealand. New Zealand: Education Forum.

Leibbrandt, M., Woolard, I., McEwen, H., \& Koep, C. (2010). Employment and Inequality Outcomes in South Africa. University of Cape Town: Southern Africa Labour and Development Research Unit.

Limb, P. (2008). The anti-apartheid movements in Australia and Aotearoa/New Zealand. The road to democracy in South Africa, 3, 907982.

Maharaj, B. (2004). Immigration to post-apartheid South Africa. Global Migration Perspectives. [Online] Available at: http://www.queensu.ca/samp/migrationresources/Documents/Maharaj_immigration.pdf. (September 11 2013).

Mail \& Guardian Online, (2007). Mismanagement of funds plagues many SA's Setas. [Online] Available at: www.mg.co.za/article/200704-24-mismangemnet-of-fundsplagies-many-sa-setas (December 12 2010).

McGrath, S., \& Akoojee, S. (2007). Education and skills for development in South Africa: Reflections on the accelerated and shared growth initiative for South Africa. International Journal of Educational Development, 27(4), 421-434.

Mda, T. (2009) Educators. In Skills Shortge in South Africa: Case studies of key professionals. HSRC: Cape Town. Pp 119-218.

Moser, C. (1998). Violence and poverty in South Africa: Their impact on household relations and social capital. South Africa Poverty and Inequality Informal Discussion Paper Series, Washington, DC: World Bank.

Murray, M. J. (1995). 'Blackbirding'at 'Crooks' corner': illicit labour recruiting in the northeastern Transvaal, 1910-1940. Journal of Southern African Studies, 21(3), 373-397.

Naicker, S., Plange-Rhule, J., Tutt, R. C., \& Eastwood, J. B. (2009). Shortage of healthcare workers in developing countries--Africa. Ethnicity \& disease, 19(1), 60.

New Zealand Department of Labour. (2005). Overview of the findings from ten professional occupation skill shortage assessment reports. [Online] Available: http://www.dol.govt.nz/PDFs/professional-report-overview.pdf (August 18 2013).

Nkomo, J. C. (2010). Development and health: the case of HIVIAIDS in southern Africa. Eastern Africa Social Science Research Review, 26(1), 111-126.

Pillay, R. (2009). Work satisfaction of professional nurses in South Africa: a comparative analysis of the public and private sectors. Human Resources for Health, 7(1), 15.

Ploch, L. (2011). South Africa: Current Issues and U.S. relations. Congressional Research Service Relations. Prepared for Members and Committees of Congress. [Online] Available at: http://www.fas.org/sgp/crs/row/RL31697.pdf (October 5 2011).

Rasool, F., Botha, C. J., \& Bisschoff, C. A. (2012). Push and Pull Factors in Relation to Skills Shortages in South Africa. Journal of Social Sciences, 30(1), 11-20.

Richardson, S. (2007). What is skills shortage? NCVER: Adelaide, Australia.

Service Publication. (2010). Lack of skills hampers service delivery. [Online] Available at: http://www.servicepublication.co.za/index.php/magazine/skills/292-lack-of-skills-hampers-service-delivery (May 19 2011)

Silva, B. (2010). Over 1700 unqualified teachers in South Africa.[Online] Available at: http://westcapenews.com/?p=1431 ( May 19 2011).

Solidarity Research Institute, (2008). Skills shortage in South Africa: summary of facts per sectors regarding this issue. [Online] Available at: www.solidarityresearch.co.za/wp.content/uploads/2010/07/16.skills-shortaginsouthafricasummary-fjc-et.pdf (November 5 2010).

Thornton, G. (2008). Lack of skills remains greatest constraints to business growth in South Africa. [Online] Available at: http://www.gt.co.za/News/Press-releases/International-business-report/2008/skills.asp. (December 2 2010].

van Rooyen, L., du Toit, D. H., Botha, E., \& Rothmann, S. (2010). Artisan retention in an organisation in South Africa. SA Journal of Human Resource Management, 8(1), 8-pages.

Wallis, G. (2002). The effect of skill shortages on unemployment and real wage growth: a simultaneous equation approach. United Kingdom: Office for National Statistics.

Weatherburn, D. (2001). What causes crime? Sydney: NSW Bureau of Crime Statistics and Research.

World Health Organization. (2006). World health Report. [Online] Available at: www.who.int/whr/2006/en/and fact on migration of health workers.www.who.int/mediacentre/factsheet/fs301/en/index.html. (January 27 2013). 
